\title{
TOUR de JNP, KEJUARAAN TAHUNAN \\ WISATA OLAH RAGA TANTANGAN PERAIRAN ANTAR DUA TAMAN NASIONAL (Inovasi Strategi Promosi Ekowisata Provinsi Jambi)
}

\author{
Ardi Novra \\ Bappeda Provinsi Jambi dan Pusat Penelitian Lingkungan Hidup \\ Lembaga Penelitian Universitas Jambi \\ ardnov@yahoo.com
}

\begin{abstract}
Ecotourism activities have been expanding rapidly over the past two decades worldwide and further growth is expected in the future. Efforts to better understand ecotourism, as well as to improve its planning, management and marketing techniques have been conducted by many ecotourism companies and practitioners, governments and research people throughout the world.

This paper is specifically concerned with the effort of the local government of Jambi to take the optimally benefit from natural tourism development more competitive. Tour de JNP (tour the Jambi National Park) is an international annual event of territorial water challenge sport-tourism to tracing river stream between Kerinci Seblat and Berbak National Park. Both national parks represent conservations area owning properties of natural tourism object which offer biodiversities. During tracing streams of Batanghari River, all participants can enjoy the esthetics value of the natural were a view of nature, air freshness and see various history and settlement of traditional cultural society.

Pursuant to stream type and deepness of river which vary, hence the setting of championship using boat type different to each phase, and will be divided on 10 phases. Entire phase will be gone through by participant by using boat type differ that is rubber boat, traditional boat of Jambi (Bidar and Kajang Lako), dragon boat, bamboo raft, and sailboat for sea and river. During race of participant will pass some tourism object were Kerinci Lake, Geo-Park, Victoria Brigde, mausoleum of Orang Kayo Hitam, Muaro Jambi Temple, Angso Duo as an eldest traditional market, Tanggo Rajo as a popular man-made tourism object, traditional settlement as long as river, Berhala Island, blackly sand of coastal area, and end in Simpang Malaka a gathering places to drinking wilds animal on the Berbak National Park.
\end{abstract}

\section{Keywords:}

ecotourism, jambi, national park, batanghari, and annual event.

\section{INTISARI}

Kegiatan ekowisata telah berkembang pesat selama dua dekade terakhir di seluruh dunia dan pertumbuhannya semakin meningkat di masa depan. Upaya untuk semakin memahami ekowisata, meliputi perencanaan, manajemen dan teknik pemasaran telah 
dilakukan oleh banyak perusahaan ekowisata, praktisi, pemerintah dan para peneliti di seluruh dunia.

Tulisan ini secara khusus menjelaskan upaya pemerintah provinsi Jambi untuk memanfaatkan secara optimal pengembangan wisata alam secara kompetitif. Tour de JNP (Tour Taman Nasional Jambi) adalah event kejuaranaan internasional tahunan berupa olah raga tantangan peraiaran dengan menelusuri aliran sungai antara Kerinci Seblat dan Taman Nasional Berbak. Kedua taman nasional merupakan daerah konservasi yang memiliki sifat-sifat objek wisata alam yang menawarkan biodiversities. Selama menelusuri aliran Sungai Batanghari, semua peserta dapat menikmati pemandangan alam, kesegaran udara, sejarah dan social budaya masyarakat.

Jenis aliran dan kedalaman sungai sangat bervariasi, maka pengaturan kejuaraan menggunakan jenis perahu yang berbeda untuk setiap fase, dan dibagi dalam 10 fase. Seluruh tahap akan ditempuh oleh peserta dengan menggunakan perahu jenis berbeda yaitu perahu karet, perahu tradisional Jambi (Bidar dan Kajang Lako), perahu naga, rakit bambu, dan perahu layar untuk laut dan sungai. Selama perlombaan peserta akan melewati beberapa obyek wisata yaitu Danau Kerinci, Geo-Park, Victoria Brigde, makam Orang Kayo Hitam, Candi Muaro Jambi, Angso Duo berupa pasar tradisional tertua, Tanggo Rajo (Objek wisata buatan), Pulau Berhala, Pasir Blackly pesisir pantai, dan berakhir di Simpang Malaka, tempat berkumpulnya hewan liar untuk minum air di Taman Nasional Berbak.

\section{Kata Kunci:}

ekowisata, jambi, taman nasional, Batanghari.

\section{PENGANTAR}

Sungai Batanghari $( \pm 3.322 \mathrm{~km})$ merupakan sungai terpanjang di Pulau Sumatera yang hampir memotong Pulau Sumatera menjadi dua bagian. DAS Batanghari $( \pm 4,9$ juta $\mathrm{Ha}$ ) merupakan daerah tangkapan air (catchment area) terbesar kedua di Indonesia dan sebagian besar berada di wilayah Provinsi Jambi (bagian hulu, tengah dan hilir DAS), sisanya di Provinsi Sumatera Barat dan Riau (hulu DAS). Secara umum DAS Batanghari terdiri dari tiga bagian dengan ciri fisik berbeda, yaitu: a). bagian hulu pada wilayah ketinggian 500-1.000 mdpl dengan curah hujan $3.000 \mathrm{~mm} /$ th dan dominasi geologi adalah pegunungan Bukit Barisan yang bersifat vulkan kuarter, b). bagian tengah terletak pada wilayah ketinggian $100-500$ mdpl dengan curah hujan $2.340 \mathrm{~mm} /$ th dan didominasi oleh bukit barisan bersifat vulkan kuarter dan c). bagian hilir terletak pada wilayah ketinggian 0-100 mdpl dengan curah hujan $2.271 \mathrm{~mm} / \mathrm{th}$ dan didominasi oleh perbukitan bergelombang endapan organosol.
Sungai yang memiliki hulu di Sumatra Barat dan bermuara di Kabupaten Tanjung Jabung Timur membelah sebagian besar kota-kota yang ada di Provinsi Jambi. Masyarakat sepanjang sungai sejak dahulu menggantungkan sebagian besar kehidupannya pada sungai ini dan terindikasi dari kotakota sepanjang DAS Batanghari sebagian besar terletak tepat di pinggir sungai. Sejak dahulu menjadi sumber kehidupan masyarakat dan merupakan akses transportasi air sebelum adanya jalan darat. Berdasarkan data Departemen Kimpraswil (2003) pada DAS Batanghari terdapat 244 desa yang meliputi \pm 180.305 Ha kawasan pertanian dan pemukiman.

Pemanfaatan sungai masih dominan untuk kepentingan irigasi sawah, pemanfaatan sumberdaya perikanan (tangkap dan budidaya) serta transportasi sungai. Belum untuk pemanfaatan jasa lingkungan bagi pengembangan pariwisata. Pada tahun 2009 sungai ini menjadi prioritas untuk dijadikan objek wisata alam menyambut tahun kunjungan wisata Jambi, karena dipandang 
layak jual. Sungai yang menjadi khasanah budaya memiliki catatan sejarah masa lampau, terutama pada masa Kerajaan Sriwijaya dan Melayu sebelum dan sesudah abad Masehi, lintasan perdagangan dunia, terutama para saudagar Arab dan Cina. Pedagang Arab menjadikan sejumlah kawasan di pinggiran Sungai Batanghari sebagai tempat peristirahatan dan sambil berdagang menyebarkan agama Islam dan hal yang sama dilakukan oleh pedagang Cina, Hong Kong, dan India yang terbukti dari penggalian sejarah, banyak ditemukan keramik kuno. Pinggiran Sungai Batangari juga menjadi tempat persembahan orang-orang Budha dan Hindu dan pada masa kerajaan Sriwijaya kawasan Candi Muaro Jambi konon menjadi tempat persembahan dan benteng pertahanan Kerajaan Sriwijaya.

Pada sisi lain pergeseran paradigma dan preferensi wisatawan mancanegara (global) dari wisata artifisial (man-made) menjadi alamiah (ecotourism) seharusnya menjadi peluang bagi pengembangan pariwisata Provinsi Jambi. Tantangan utama yang dihadapi sektor pariwisata adalah masih rendahnya daya saing dibanding daerah lain, sehingga dibutuhkan suatu inovasi kreatif dalam menyusun strategi pemasaran dan promosi wisata alam. Salah satu pendekatan yang terbukti efektif dalam promosi wisata adalah melalui kejuaraan tahunan berskala internasional. Rute kejuaraan yang ditawarkan adalah mengarungi aliran 5 sungai (Batang Merangin, Batang Tembesi, Batang Hari, Sungai Berbak dan Air Hitam) dan pantai timur (Selat Berhala). Jalur ini menghubungkan antara kawasan TNKS (Kabupaten Kerinci) sebagai kawasan konservasi dataran tinggi (highland) dan TNB (Tanjung Jabung) sebagai kawasan konservasi dataran rendah (wetland). Alternatif nama kejuaraan antara lain Tour de Jambi Adventure, Jambi Tour de River, Jambi River Adventure Rally, Tour de Jambi National Park, dan nama lain yang ditinjau dari aspek pemasaran mampu meningkatkan brand image dan preferensi spesifik dan menarik bagi peserta dan wisatawan.

\section{PARIWISATA DAN PEREKONOMIAN}

\section{Peranan Pariwisata dalam \\ Perekonomian}

Menurut UNESCO (Wells, 1997) sektor pariwisata memainkan peranan signifikan dalam perekonomian 11 dari 20 negara miskin di dunia, satu dari dua negara berpendapatan rendah (low-income countries) dan hampir seluruh negara berpendapatan menengah (middle-income countries). Pada situasi pembangunan normal pariwisata dapat digunakan sebagai alat yang efektif dalam memberantas kemiskinan dan memberikan kontribusi bagi upaya perbaikan (redevelopment) berbagai kegagalan pembangunan pedesaan dan perkotaan. Pertumbuhan ekonomi yang dihasilkan dari pembangunan pariwisata sering memberikan "benefit" bagi kelestarian budaya dan alam melalui program peningkatan alokasi sumber daya publik yang tidak hanya signifikan mempengaruhi sosial ekonomi tetapi mampu melindungi warisan budaya (Carney, 1998) Ekowisata merupakan upaya meningkatkan proteksi terhadap kawasan alamiah melalui peningkatan benefit ekonomi komunitas lokal, organisasi dan pengelola kawasan konservasi, peningkatan kepedulian komunitas lokal dan pengunjung (turis) terhadap aset-aset konservasi alam dan sosial budaya, penyusunan konsep yang efisien dan adil untuk perlindungan keanekaragaman hayati dan budaya, dan perhatian dan monitoring lebih untuk kawasan yang sensitif serta pengakuan terhadap hak indogenous dan tradisional pada areal yang suitable dalam pembangunan ekowisata (WTO-UNEP, 2002).

Tahun Pariwisata Alam Internasional (The International Year of Eco tourim) menawarkan suatu kerangka kerja konsolidasi alat dan kelembagaan untuk pembangunan berkelanjutan dimasa akan datang, terutama dalam memaksimalkan benefit ekonomi, lingkungan dan sosial dari aktifitas ekowisata (WTO- 
UNEP, 2002). Kerangka kerja konsolidasi sektor pariwisata guna mencapai tujuan menuntut partisipasi semua pihak dalam aktifitas ekowisata antara lain a) meningkatkan kepedulian otoritas publik, sektor swasta, masyarakat sipil dan konsumen untuk menghargai kapasitas ekowisata dalam mendorong konservasi warisan alam dan budaya pada kawasan alamiah pedesaan dan memperbaiki standar kehidupan masyarakat kawasan, b) penyebaran metode dan teknik untuk perencanaan, manajemen, regulasi dan monitoring untuk menjamin keberlanjutan jangka panjang, dan c) mendorong pertukaran pengalaman keberhasilan dalam bidang ekowisata, dan peningkatan efisiensi pasar dan promosi tujuan dan produk di pasar dunia.

\section{Potensi dan Peranan Sektor Pariwisata Provinsi Jambi}

Perkembangan sektor pariwisata di Provinsi Jambi relatif lambat dibanding daerah lainnya di regional Sumatera. Berbagai program dalam upaya peningkatan jumlah kunjungan wisatawan nasional dan mancanegara relatif masih rendah meskipun Provinsi Jambi memiliki keanekaragaman objek wisata baik wisata alam, budaya maupun sejarah. Jumlah wisatawan manca negara yang menginap pada hotel berbintang selama tahun 2008 baru mencapai 3.669 orang, wisatawan domestik 166.634 orang, dengan rata-rata menginap 1,39 - 2,88 hari (JDA, 2009).

Pada tahun 2008 tercatat 285 lokasi wisata yang sebagian besar merupakan objek wisata alam (114) dan objek wisata sejarah dan budaya (63) dan sisanya merupakan objek wisata buatan (39). Seluruh objek wisata ini tersebar pada 10 wilayah adminstrasi dengan jumlah objek wisata alam terbanyak di Kabupaten Kerinci (44 lokasi). Sarana penunjang pengembangan pariwisata yang sudah tersedia antara lain restoran/ rumah makan (447 buah), hotel (128 buah) yang meningkat $7,09 \%$ dari tahun sebelumnya dan diikuti kenaikan jumlah kamar dan tempat tidur sebesar 6,90\%. Ratarata tingkat hunian hotel dan akomodasi lainnya untuk hotel berbintang $49,77 \%$ dan hotel melati 36,87\%.

Kontribusi sektor pariwisata (rekreasi dan hiburan) terhadap PDRB Provinsi Jambi hanya sebesar $0,07 \%$, sedangkan sektor terkait berupa hotel dan restoran baru mencapai 1,13\%. Padahal sektor pariwisata tidak hanya mampu menjadi pengerak perkembangan sektor terkait lainnya tetapi juga dapat menciptkan permintaan turunan (derived demand) terhadap berbagai industri pengolahan barang dan jasa. Perkembangan pariwisata mampu mendorong berkembangnya usaha kecil dan menengah (UKM) terutama dalam bidang kerajinan tangan (cindera mata), jasa perdagangan dan bahkan jasa transportasi dan komunikasi. Rendahnya kontribusi sektor pariwisata dan sektor terkait langsung ini terhadap PDRB menyebabkan daya serap tenaga kerja sektor pariwisata diduga juga sangat rendah sehingga proporsi penduduk usia kerja yang berkerja pada sektor ini juga sangat rendah.

\section{Inovasi Strategi Promosi Ekowisata Daerah}

Pengembangan ekowisata berbasis potensi alam (nature based) seperti topografi, air, cuaca, hutan, kebudayaan/peninggalan purbakala dan alam sebagai pendukung (nature related) yaitu pertanian, agrowisata, olah raga seperti wisata petualangan hutan rimba di alam bebas, pengamatan satwa liar, atraksi budaya dan sebagainya (Kusudianto, 1996 dalam Agus-manto, 2006). Bussines Meeting of the Junior Chamber International di Bali (1994) menyatakan semboyan Produce More with Less Energy, Less Waste menunjukkan bahwa perubahan sistem pengembangan pariwisata untuk lebih mempertimbangkan kelestarian sumberdaya alam dan lingkungan. Wisatawan ekowisata bukan lagi dalam bentuk masstourism mengunjungi suatu negara dalam waktu singkat tetapi menjadi kelompok kecil (niche-tourism) yang ingin tinggal lebih lama. Wisatawan ekowisata gemar mengikuti 
petualangan seperti arung jeram, berjalan kaki beberapa hari, menginap dengan akomodasi sederhana serta melintas rimba dan memanjat gunung (Kusudianto, 1996 dalam Agusmanto, 2006).

Pemanfaatan event olah raga sebagai bagian dari strategi promosi ekowisata sudah mulai dikembangkan oleh pemerintah daerah dalam beberapa momen tertentu, antara lain; a) lomba perahu naga dalam HUT Provinsi Jambi dan kemerdekaan tujuh belas agustus, b) lomba perahu dalam festival Danau Kerinci yang telah menjadi kegiatan tahunan dan bertujuan sebagai ajang promosi wisata alam dan budaya Kabupaten Kerinci, dan c) lomba perahu tradisional dalam festival Batanghari yang menjadi agenda tahunan Pemerintah Kabupaten Batanghari, serta d) lomba perahu bidar di Kabupaten Sarolangun.

Merebut pangsa pasar wisata relatif sulit mengingat tingginya tingkat persaingan pasar wisata terutama dengan daerah lain yang telah terlebih dahulu berkembang dan dikenal sebagai tujuan utama wisatawan. Beberapa faktor yang menyebabkan rendahnya daya saing Provinsi Jambi dalam pasar wisata regional dan nasional antara lain:

a. Kegiatan yang ditawarkan sama dan telah banyak berkembang pada wilayah lain sehingga bukan merupakan sesuatu yang sangat spesifik dan menjadi daya tarik utama dalam peningkatan daya saing wisata Provinsi Jambi.

b. Secara ekonomi, biaya yang harus dikeluarkan (willingness to pay) wisatawan mancanegara jauh lebih besar dibanding nilai manfaat yang mereka terima (willingness to accept) karena tawaran objek wisata yang dapat dinikmati oleh wisatawan relatif sedikit.

c. Kondisi infrastruktur utama dan menuju kawasan yang masih kurang baik sehingga dibutuhkan waktu dan biaya cukup besar untuk menuju objek wisata dalam suatu periode kunjungan wisatawan.

d. Jika ada wisatawan bersedia datang dan berkunjung maka lama tinggal di lokasi kegiatan relatif singkat sehingga efek kunjungan wisatawan bagi perekonomian daerah relatif kecil.

Untuk itu dibutuhkan suatu strategi pemasaran dan promosi pariwisata daerah yang lebih terintegrasi dan memilki daya saing dengan daerah tujuan wisata lainnya. Beberapa syarat yang perlu dipenuhi dalam pengembangan strategi pariwisata yang berdaya saing adalah;

a. Mampu memenuhi atau mengikuti perubahan preferensi konsumen pariwisata global (wisatawan manca negara) yaitu back to nature atau menawarkan sesuatu yang masih alami.

b. Merupakan sesuatu yang sangat spesifik daerah sehingga sulit dijumpai pada wilayah lain dan menawarkan jasa lingkungan (environmental service) yang bervariasi (keanekaragaman).

c. Merupakan suatu paket wisata yang didesain terintegrasi dan mampu menyediakan hiburan dan bahkan tantangan bagi wisatawan manca negara.

d. Berdasarkan ketiga hal diatas maka diharapkan rasio antara biaya yang harus dikeluarkan (willingness to pay) dan manfaat yang diperoleh (willingness to accept) para wisatawan dapat lebih berimbang.

e. Merupakan suatu kegiatan yang tidak hanya mampu memperbesar jumlah kunjungan tetapi juga memperlama waktu tinggal wisatawan di Provinsi Jambi.

Salah satu alternatif strategi yang dapat dilakukan adalah melalui integrasi olah raga tantangan perairan yang dilengkapi dengan sajian keberagaman potensi wisata alam dan budaya daerah, sehingga keunggulan Sungai Batanghari yang menjadi kebanggaan masyarakat Provinsi Jambi dapat lebih termanfaatkan, yaitu;

a. Menjadi penghubung antara 2 (dua) taman nasional yang memiliki kekayaan objek wisata dan keanekaragaman hayati yang kontras berbeda. TNKS

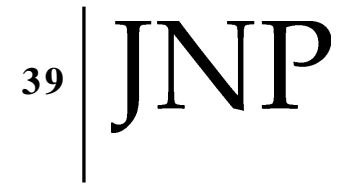


merupakan kawasan konservasi dataran tinggi (high land) sedangkan TNB merupakan kawasan konservasi dataran rendah sehingga keduanya memiliki kekhasan tersendiri dan diakui dunia.

b. Sepanjang sungai yang menghubungkan 2 taman nasional terdapat berbagai objek wisata alam dan budaya mulai dari hulunya di Danau Kerinci, GeoPark Kabupaten Merangin, Jembatan Beatrix Kabupaten Sarolangun, pemukiman tradisional dari Kabupaten Batanghari sampai Tanjab Timur, Candi Muaro Jambi di Kabupaten Muaro Jambi.

c. Aliran sungai penghubung kedua taman nasional karena mengalir dari dataran tinggi ke dataran rendah (pantai timur) memiliki kecepatan arus dan kedalaman yang berbeda sehingga sesuai untuk pengembangan berbagai jenis olahraga tantangan perairan.

d. Kombinasi berbagai jenis olah raga tantangan dalam satu aliran yang menghubungkan dua taman nasional dengan kekayaan dan keanekaragaman hayati (flora dan fauna) yang berbeda akan potensial menjadi suatu kegiatan yang spesifik dan satu-satunya di dunia.

\section{DESAIN TOUR de JNP}

\section{Desain Tour de JNP}

Kejuaraan olah raga tantangan perairan di alam bebas dilaksanakan sepanjang daerah aliran sungai (DAS) Batanghari yang menghubungkan 2 kawasan konservasi yaitu Taman Nasional Kerinci Seblat (TNKS) dan Taman Nasional Berbak (TNB). Kejuaraan internasional tahunan (annual international event) melalui 7 kabupaten/kota di lingkup wilayah adminsitrasi Provinsi Jambi yaitu Kabupaten Kerinci, Merangin, Sarolangun, Batang Hari, Muaro Jambi, Tanjung Jabung Timur dan Kota Jambi. Perlombaan sesuai dengan jumlah wilayah persinggahan akan dibagi dalam 9 etape lomba perahu menelusuri sungai dan 1 etape untuk lomba perahu layar mengarungi pantai Timur Provinsi Jambi. Start pertama akan dilakukan di Kabupaten Kerinci dan berakhir atau finish setelah mengitari Pulau Berhala yang selanjutnya memasuki Sungai Air Hitam Laut dan berakhir di Simpang Malaka dalam kawasan TNB.

Filosofi dari pembagian etape dalam kejuaraan internasional tahunan dalam rangka promosi wisata alam Jambi ini mengandung makna bahwa kejuaraan dilaksanakan di Negeri Sepucuk Jambi Sembilan Lurah. Merujuk pada Peraturan Daerah Provinsi Jambi No.1/1969, kalimat "SEPUCUK JAMBISEMBILAN LURAH" di dalam satu pita bergulung tiga dan kedua belah ujungnya bersegi dua melambangkan kebesaran kesatuan wilayah geografis 9DAS dan lingkup wilayah adat Jambi "SIALANG BELANTAK BESI SAMPAI DURIAN BATAKUK RAJO DAN DIOMBAK NAN BADABUR, TANJUNG JABUNG". Untukitu desain kejuaraan sebagai bentuk strategi pemasaran dan promosi wisata Provinsi Jambi ini mengandung makna sebagai berikut:

a. Kata "SEMBILAN" mengandung makna bahwa kejuaraan yang dimulai di dataran tertinggi Provinsi Jambi yaitu Danau Kerinci yang merupakan bagian dari kawasan TNKS untuk sampai pada wilayah Pantai Timur akan melalui sembilan etape sepanjang aliran sungai dan anak sungai Batang Hari menuju kawasan pantai timur.

b. Kata "SEPUCUK" berarti paling ujung dari sebatang pohon mengandung makna bahwa lomba akan berakhir pada kawasan Ombak Nan Badabur Tanjung Jabung dalam bentuk lomba perahu layar mengitari Pulau Berhala untuk sampai ke Desa Air Hitam Laut yang merupakan pintu masuk menuju kawasan TNB dengan lintasan berbentuk daun.

Tujuan utama penyelenggaraan event tahunan berskala internasional dalam bentuk kejuaraan wisata olah raga tantangan perairan (Tour de Jambi National Park atau Tour de JNP) 
adalah sebagai upaya promosi wisata alam daerah dalam rangka meningkatkan kontribusi sektor pariwisata dalam perekonomian daerah. Secara lebih spesifik tujuan pengembangan strategi pemasaran dan promosi wisata alam ini adalah:

a. Memperkenalkan objek-objek wisata alam, budaya dan sejarah yang tersebar di wilayah Provinsi Jambi.

b. Menciptakan image wisata yang lebih baik, spesifik dan memiliki daya saing bagi wisatawan.

c. Meningkatkan jumlah kunjungan wisatawan.

d. Meningkatkan lama tinggal wisatawan di Provinsi Jambi.

e. Meningkatkan kontribusi sektor pariwisata terhadap perekonomian daerah.

f. Mengembangkan pembangunan ramah lingkungan dan memberikan nilai tambah manfaat bagi perekonomian masyarakat dan daerah.

\section{Rangkaian Kegiatan dalam Kejuaraan Internasional Tahunan}

Rangkaian kegiatan di setiap lokasi persinggahan akan tampilkan atraksi seni dan budaya masing-masing daerah serta kunjungan pada beberapa objek wisata. Skema wilayah pelaksanaan dan titik-titik lokasi persinggahan rangkaian kegiatan dalam Tour de JNP disajikan pada Gambar 1.

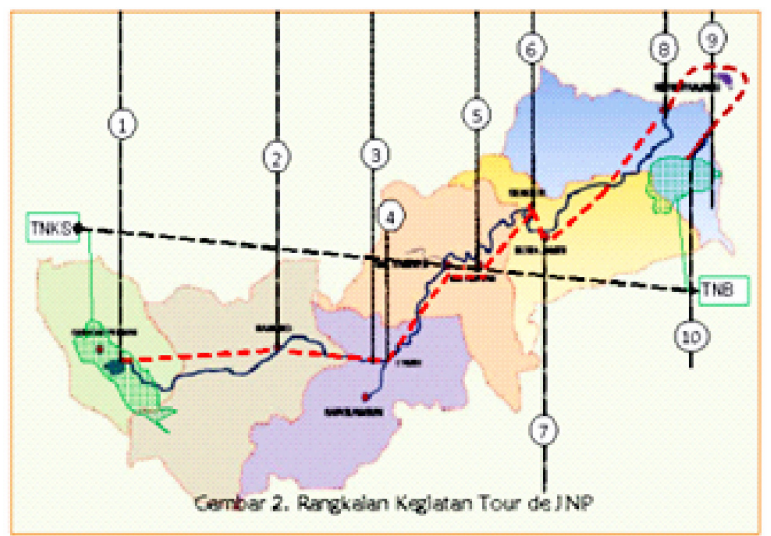

Gambar 1. Lokasi Pelaksaksanaan Kegiatan.

Pemilihan jenis perahu yang diperlombakan didasarkan kepada type aliran sungai (deras dan lambat), kedalaman sungai, jarak tempuh (pendek dan panjang) serta pertimbangan penilaian (kecepatan, ketepatan waktu, penampilan serta kekompakan tim). Lomba yang menggunakan faktor kecepatan sebagai penilaian adalah arung jeram, perahu naga. Lainnya diadakan sepanjang aliran anak sungai Batang Merangin, Batang Tambesi dan Batanghari serta beberapa lomba perahu jarak pendek pada setiap lokasi persinggahan lomba jarak panjang. Lomba jarak panjang lainnya dikemas dalam bentuk rally.

Tabel 1.

Kegiatan Utama dalam Kejuaraan Internasional Tahunan Wisata Olahraga Tantangan Perairan Antara 2 Taman Nasional

\begin{tabular}{|c|l|c|c}
\hline No. & \multicolumn{1}{|c|}{ Lokasi Lomba } & Jenis Perahu/Lomba & Status Lomba \\
\hline 1 & Sungai Penuh/Kerinci & Arung Jeram & Jarak Jauh \\
\hline 2 & Merangin & Arung Jeram & Jarak Jauh \\
\hline 3 & \multirow{2}{*}{ Sarolangun } & Lomba Perahu Bidar & Jarak Pendek \\
\cline { 3 - 4 } & & Perahu Tradisonal & Jarak Jauh \\
\hline 4 & \multirow{2}{*}{ Batanghari } & Perahu Naga & Jarak Pendek \\
\cline { 3 - 4 } & & Perahu Tradisional & Jarak Jauh \\
\hline 5 & Muaro Jambi & Perahu Rakit & Jarak Jauh \\
\hline 6 & \multirow{2}{*}{ Kota Jambi } & Perahu Kano & Jarak Pendek \\
\cline { 3 - 4 } & & Perahu Layar Sungai & Jarak Jauh \\
\hline 7 & Kabupaten Tanjabtim & Perahu Layar Laut & Jarak Jauh \\
\hline
\end{tabular}

Tabel 1 menunjukkan bahwa awal event di Danau Kerinci yang terdapat pada kawasan TNKS dan setelah melewati beberapa kota dan mengitari Pulau Berhala dengan menggunakan berbagai jenis perahu akan berakhir di kawasan TNB. Pada setiap lokasi persinggahan akan dimeriahkan berbagai kegiatan seni dan budaya tradisional masingmasing daerah serta kunjungan pada beberapa objek wisata alam, budaya dan sejarah sepanjang aliran Sungai dan Anak Sungai Batanghari, Pantai Timur dan Sungai Air Hitam sebagai pintu masuk TNB. Sinkronisasi waktu yang paling tepat sebagai acuan adalah HUT Provinsi Jambi tanggal 6 Januari, sehingga pelepasan awal di Kabupaten Kerinci dapat dilakukan pada setiap akhir tahun yang berbarengan dengan kedatangan pencinta alam untuk mendaki gunung dalam rangka perayaan Tahun Baru. Jumlah hari dibutuhkan jika dilaksanakan secara terintegrasi dengan target mencapai kota pusat pemerintahan Provinsi Jambi pada saat HUT Jambi adalah 21 hari (Tabel 2). 
Tabel 2.

Waktu Pelaksanaan Kejuaraan Internasional Tahunan Wisata Olahraga Tantangan Perairan Antara 2 Taman Nasional

\begin{tabular}{|c|c|c|c|}
\hline No. & Kab./Kota & Route Perlombaan & Waktu \\
\hline \multirow[t]{2}{*}{1} & \multirow[t]{2}{*}{ Kerinci } & $\begin{array}{c}\text { Pembukaan (Festival } \\
\text { Kerinci) }\end{array}$ & 27 - 31 Des \\
\hline & & $\begin{array}{c}\text { Danau Kerinci - } \\
\text { Geopark - Bangko }\end{array}$ & 1 Januari \\
\hline 2 & Merangin & $\begin{array}{c}\text { Kota Bangko - Muara } \\
\text { Batang Merangin }\end{array}$ & 2 Januari \\
\hline \multirow[t]{2}{*}{3} & \multirow[t]{2}{*}{ Sarolangun } & $\begin{array}{l}\text { Hulu Batang Tambesi - } \\
\text { Jembatan Beatrix }\end{array}$ & 2 Januari \\
\hline & & $\begin{array}{c}\text { Jembatan Beatrix - } \\
\text { Muara Tambesi } \\
\end{array}$ & 3 Januari \\
\hline \multirow[t]{2}{*}{4} & \multirow[t]{2}{*}{ Batanghari } & $\begin{array}{l}\text { M. Tambesi - Muaro } \\
\text { Bulian }\end{array}$ & 4 Januari \\
\hline & & M. Bulian - Desa Selat & 4 Januari \\
\hline 5 & Muaro Jambi & $\begin{array}{c}\text { Desa Selat - Jembatan } \\
\text { Batanghari } 1\end{array}$ & 5 Januari \\
\hline \multirow[t]{2}{*}{6} & \multirow[t]{2}{*}{ Kota Jambi } & $\begin{array}{c}\text { Jembatan BH } 1 \text { - } \\
\text { Wisata Tanggo Rajo }\end{array}$ & 6 Januari \\
\hline & & $\begin{array}{c}\text { Kota- Candi - Makan } \\
\text { Keramat - Nipah } \\
\text { Panjang } \\
\end{array}$ & 7 Januari \\
\hline 7 & $\begin{array}{l}\text { Kab. } \\
\text { Tanjabtim }\end{array}$ & $\begin{array}{c}\text { Nipah Panjang - Pulau } \\
\text { Berhala- } \\
\text { Air Hitam Laut - TNB }\end{array}$ & $8-9$ Januari \\
\hline
\end{tabular}

Konsekuensi yang timbul dari pelaksanaan kegiatan ini adalah menyesuaikan jadwal kegiatan yang sudah eksis sebelumnya, seperti: Festival Danau Kerinci dan Festival Sungai Batanghari, Mandi Sya'far di Pantai Air Hitam Laut Tanjung Jabung Timur. Sebaliknya jika tidak maka dapat dilakukan terpisah dan tidak dapat diintroduksi ke dalam event. Jumlah hari kegiatan yang dibutuhkan menjadi salah satu pilihan strategis dalam promosi pariwisata dan peningkatan volume penjualan jasa dan barang lokal yang menjadi pendukung kegiatan.

\section{Sistem Kejuaraan dan Target Peserta}

Kejuaraan diklasifikasikan atas 2 kelompok yaitu kejuaraan kelompok (group) berdasarkan hasil akumulasi seluruh etape yang dilewati dan perorangan terutama untuk jenis lomba jarak pendek. Pemenang akan ditentukan pada setiap etape dan akumulasi nilai akan menentukan kelompok yang akan mendapatkan nilai tertinggi sampai berakhirnya kejuaraan (finish). Juara setiap etape baik individual maupun group akan memperoleh hadiah dan berhak untuk mengenakan pakaian khusus sebagai bentuk penghargaan pada etape selanjutnya. Jaket berwarna pinang masak (orange) sebagai warna flora khas dalam lambang wilayah Provinsi Jambi untuk juara setiap etape dan jaket warna hijau daun sebagai bentuk kecintaan terhadap kelestarian alam. Target peserta lomba dalam kejuaraan internasional tahunan wisata olah raga tantangan perairan ini berasal dari berbagai unsur, yaitu a) peserta lokal yaitu perwakilan Kabupaten/Kota di Provinsi Jambi atau kelompok peserta tertentu yang bukan mewakili wilayah, b) perwakilan daerah dan kelompok berbagai wilayah lain diluar Provinsi Jambi dan c) perwakilan kelompok dari berbagai negara partisipan.

Setiap jenis lomba tim memiliki jumlah atlit yang berbeda sesuai dengan jenis perahu yang digunakan, sehingga dalam 10 etape kegiatan dengan 8 jenis perahu berbeda maka setiap atlit dituntut memiliki beberapa spesifikasi olah raga perairan baik untuk lomba yang sifatnya individual maupun tim. Penentuan jumlah atlit setiap tim sesuai dengan kebutuhan untuk masing-masing lomba dengan rincian seperti pada Tabel 3.

Tabel 3.

Jenis dan Status Lomba serta Jumlah Perahu dan Peserta

\begin{tabular}{|c|l|c|c|c|c|c|}
\hline \multirow{2}{*}{ No. } & \multirow{2}{*}{ Jenis Lomba } & \multicolumn{2}{|c|}{ Status Lomba } & \multirow{2}{*}{ Perwakilan } & \multicolumn{2}{c|}{ Jumlah Peserta Setiap } \\
& & Indiviudal & Group & Gorup & Perahu & / Group \\
\hline 1 & Arung Jeram & $\sqrt{ }$ & $\sqrt{ }$ & 2 & 7 & 14 \\
\hline 2 & Arung Jeram & $\sqrt{ }$ & $\sqrt{ }$ & 2 & 7 & 14 \\
\hline 3 & Perahu Bidar & $\sqrt{ }$ & $\sqrt{ }$ & 2 & 8 & 16 \\
\hline 4 & $\begin{array}{l}\text { Perahu } \\
\text { Tradisonal }\end{array}$ & & $\sqrt{ }$ & 1 & 12 & 12 \\
\hline 5 & Perahu Naga & & $\sqrt{ }$ & 1 & 17 & 17 \\
\hline 6 & $\begin{array}{l}\text { Perahu } \\
\text { Tradisional }\end{array}$ & & $\sqrt{n n n n n}$ & 1 & 12 & 12 \\
\hline 7 & Perahu Rakit & & $\sqrt{ }$ & 3 & 2 & 6 \\
\hline 8 & Perahu Angsa & & $\sqrt{ }$ & 1 & 12 & 12 \\
\hline 9 & $\begin{array}{l}\text { Perahu Layar } \\
\text { Sungai }\end{array}$ & & $\sqrt{ }$ & 2 & 5 & 10 \\
\hline 10 & $\begin{array}{l}\text { Perahu Layar } \\
\text { Laut }\end{array}$ & & $\sqrt{n n n n n n}$ & 2 & 7 & 14 \\
\hline
\end{tabular}

Berdasarkan pada Tabel 3. jumlah atlet minimal untuk setiap kelompok adalah sebanyak jumlah peserta untuk lomba perahu naga yang mencapai 19 orang tetapi dengan untuk mengurangi resiko maka perlu dilengkapi dengan 6 atlit cadangan sehingga 
menjadi 25 orang. Hal ini berarti bahwa seluruh atlit dalam tim harus memiliki keterampilan dalam lomba perahu naga sedangkan untuk jenis perahu lain disesuaikan dengan jumlah peserta setiap etape. Jumlah minimal ini dapat dilakukan jika seluruh atlit dari masing-masing tim menguasai beberapa jenis perahu yang berbeda tetapi jika tidak maka penambahan atlit menjadi suatu kebutuhan. Berdasarkan kepada berbagai pertimbagan dengan memperhatikan keterbatasan atlit dayung maka perkiraan jumlah atlit setiap tim disajikan pada Tabel 4.

Tabel 4.

Estimasi Jumlah Partisipan setiap Grup

\begin{tabular}{|c|l|c|c|}
\hline \multirow{2}{*}{ No. } & \multirow{2}{*}{ Status Partisipan } & \multicolumn{2}{|c|}{ Jumlah Atlit (Orang) } \\
\cline { 3 - 4 } & & Minimal & Maksimal \\
\hline 1 & Manajer Tim & 1 & 2 \\
\hline 2 & Atlit & 25 & 30 \\
\hline 3 & Teknisi & 2 & 4 \\
\hline 4 & Lainnya & 2 & 4 \\
\hline & Jumlah & 30 & 40 \\
\hline
\end{tabular}

Berdasarkan jumlah atlit dan variasi jenis lomba maka pelibatan jumlah atlit dalam setiap etape juga bervariasi kecuali pada saat lomba perahu naga. Hal ini menyebabkan lomba perahu tertentu hanya atlit yang menjadi andalan tim yang akan turun sedangkan untuk atlit lain memiliki kesempatan untuk beristirahat. Pendekatan lomba seperti ini tidak hanya memberikan keuntungan bagi setiap tim untuk mempersiapkan atlit dengan tingkat kesegaran optimal tetapi juga memberi kesempatan untuk mengunjungi beberapa objek wisata wilayah kegiatan. Strategi tim dalam menentukan siklus atlit yang menjadi andalan untuk setiap etape akan menjadi faktor penentu utama untuk memenangkan kejuaraan.

\section{REKOMENDASI KEBIJAKAN}

Berdasarkan kajian analisis deskriptif kejuaraan tahunan skala internasional wisata olah raga tantangan perairan dapat dilakukan sebelum implementasi;

1. Menyusun konsep detail desain, mencakup kelayakan aliran sungai, teknis dan finansial serta strategi pengembangan wisata promosi dan pemasaran.

2. Mendaftarkan kegiatan dalam daftar agenda nasional Kemenparekraf RI.

3. Perluasan promosi skala internasional dengan usulan proposal pada World Tourism Organization (WTO).

\section{DAFTAR REFERENSI}

Agusmanto, 2004. Pengembangan Ekowisata Alam dan Budaya di Kabupaten Merangin, Propinsi Jambi, Tugas Akhir Jurusan Perencanaan Wilayah dan Kota, Fakultas Teknik Universitas Diponegoro, Semarang.

Ashley C., C. Boyd and H. Goodwin, 2000. Pro-Poor Tourism: Putting Poverty at the Heart of Tourism Agenda, Department for International Development (DfID), United Kingdom.

Balai TNB (Taman Nasional Berbak), 2006. Rencana Kerja Pengelolaan Taman Nasional Berbak, Balai TNB, Jambi.

Carney D., 1998. Sustainable Rural Livelihoods: What Contribution Can We Make? London: DFID.

Kimpraswil.2003.Penyusunan Arahan Pemanfaatan Ruang di DAS Batanghari. Direktorat Penataan Ruang Wilayah Barat Direktorat Jenderal Penataan Ruang Departemen, Browsing: http:// penataanruang.pu.go.id/ta/Lapak04/ P3.html.

Moutinho, L. 2000, Strategic Management in Tourism. CAB International Publishing, New York

Wells, M. P., 1997. Economic Perspectives on the Nature Tourism, Conservation and Development, an Environmentally Sustainable Development, the World Bank, 
ESD Pollution and Environmental, New York.

Wiguna, R. 2010. (Ironi) Sungai Batang Hari dan Masyarakatnya, Kompasiana, Kolom Opini, Browsing: http:// kompas.com. tanggal 24 Maret 2010
WTO-UNEP, 2002. Torurism Economics Perspective, WTO-UNEP Concept Paper on International Year of Eco tourism, New York. 